\title{
Genetic analysis of coagulation properties, curd firming modeling, milk yield, composition, and acidity in Sarda dairy sheep
}

\author{
G. Bittante, ${ }^{*}$ C. Cipolat-Gotet, ${ }^{*}$ M. Pazzola, $†$ M. L. Dettori, $\dagger$ G. M. Vacca, $\dagger$ and A. Cecchinato*1 \\ *Department of Agronomy, Food, Natural Resources, Animals and Environment (DAFNAE) University of Padova, \\ viale dell'Università 16 - 35020 Legnaro (PD), Italy \\ †Department of Veterinary Medicine, University of Sassari, Via Vienna 2, 07100 Sassari, Italy
}

\begin{abstract}
Sheep milk is an important source of food, especially in Mediterranean countries, and is used in large part for cheese production. Milk technological traits are important for the sheep dairy industry, but research is lacking into the genetic variation of such traits. Therefore the aim of this study was to estimate the heritability of traditional milk coagulation properties and curd firmness modeled on time t $\left(\mathrm{CF}_{\mathrm{t}}\right)$ parameters, and their genetic relationships with test-day milk yield, composition (fat, protein, and casein content), and acidity in Sarda dairy sheep. Milk samples from 1,121 Sarda ewes from 23 flocks were analyzed for 5 traditional coagulation properties by lactodynamographic tests conducted for up to 60 min: rennet coagulation time (min), curd-firming time $\left(\mathrm{k}_{20}, \mathrm{~min}\right)$, and 3 measures of curd firmness $\left(\mathrm{a}_{30}\right.$, $\mathrm{a}_{45}$, and $\mathrm{a}_{60}, \mathrm{~mm}$ ). The 240 curd firmness observations (1 every $15 \mathrm{~s})$ from each milk sample were recorded, and 4 parameters for each individual sample equation were estimated: rennet coagulation time estimated from the equation $\left(\mathrm{RCT}_{\text {eq }}\right)$, the asymptotic potential curd firmness $\left(\mathrm{CF}_{\mathrm{P}}\right)$, the curd firming instant rate constant $\left(\mathrm{k}_{\mathrm{CF}}\right)$, and the syneresis instant rate constant $\left(\mathrm{k}_{\mathrm{SR}}\right)$. Two other derived traits were also calculated $\left(\mathrm{CF}_{\max }\right.$, the maximum curd firmness value; and $t_{\max }$, the attainment time). Multivariate analyses using Bayesian methodology were performed to estimate the genetic relationships of milk coagulation properties and $\mathrm{CF}_{\mathrm{t}}$ with the other traits; statistical inference was based on the marginal posterior distributions of the parameters of concern. The marginal posterior distribution of heritability estimates of milk yield $(0.16 \pm 0.07)$ and composition $(0.21 \pm 0.11$ to $0.28 \pm 0.10)$ of Sarda ewes was similar to those often obtained for bovine species. The heritability of rennet coagulation time as a single point trait was also similar to that frequently obtained for cow
\end{abstract}

Received March 24, 2016.

Accepted September 8, 2016.

${ }^{1}$ Corresponding author: alessio.cecchinato@unipd.it milk $(0.19 \pm 0.09)$, whereas the same trait calculated as an individual equation parameter exhibited larger genetic variation and a higher heritability estimate $(0.32$ \pm 0.11 ). The other curd firming and syneresis traits, whether as traditional single point observations or as individual equation parameters and derived traits, were characterized by heritability estimates lower than for coagulation time and for the corresponding bovine milk traits (0.06 to 0.14). Phenotypic and additive genetic correlations among the 11 technological traits contribute to describing the interdependencies and meanings of different traits. The additive genetic relationships of these technological traits with the single test-day milk yield and composition were variable and showed milk yield to have unfavorable effects on all measures of curd firmness $\left(\mathrm{a}_{30}, \mathrm{a}_{45}, \mathrm{a}_{60}, \mathrm{CF}_{\mathrm{P}}\right.$, and $\left.\mathrm{CF}_{\max }\right)$ and $\mathrm{t}_{\max }$, but favorable effects on both instant rate constants $\left(\mathrm{k}_{\mathrm{CF}}\right.$ and $k_{\mathrm{SR}}$ ). Milk fat content had a positive effect on curd firmness traits, especially on those obtained from $\mathrm{CF}_{t}$ equations, whereas the negative effects on both coagulation time traits were attributed to the milk protein and casein contents. Finally, in view of the estimated heritabilities and additive genetic correlations, enhancement of technological traits of sheep milk through selective breeding could be feasible in this population.

Key words: heritability, sheep milk, milk coagulation properties, curd-firming modeling, cheese-making

\section{INTRODUCTION}

The ovine species contributes significantly to overall milk production, especially in countries of the Mediterranean Basin, Central and Eastern Europe, and the Middle East, with an estimated economic value of approximately US $\$ 5,600$ million (FAOSTAT, 2014). The island of Sardinia is the region of the Mediterranean basin with the highest concentration of dairy sheep (about 3 million head on 24,090 $\mathrm{km}^{2}$ ), and the Sarda sheep breed, now also reared in other Italian regions and other countries, is the most numerous specialized dairy sheep breed found there (Astruc et al., 2008). 
Selective breeding of dairy sheep populations is not carried out as with the bovine species because, although the cost of milk recording and analysis, flock-book organization, and breeding value estimation is similar to the major species, individual milk yield and economic value are much smaller, making the income/cost ratio much less favorable. Selection of dairy sheep breeds is often carried out through pyramidal management of populations, with nucleus flocks enrolled in flock-books at the top, performing milk recording, practicing artificial or controlled natural mating, and using estimated breeding values as selection criteria (Macciotta et al., 2005). This nucleus provides semen and rams for spreading genetic improvement in commercial flocks, as reviewed by Carta et al. (2009), according to whom current genetic improvement in dairy sheep populations is generally aimed at increasing milk yield and, especially in the case of French breeds, milk fat and protein yields or percentages (or both). In a few cases, SCC and udder traits are included in the selection indices (Carta et al., 2009; de la Fuente et al., 2011).

The heritability of milk yield of dairy ewes is well known (Pollott and Gootwine, 2001; Gutiérrez et al., 2007), as are the genetic parameters of somatic cell content (el-Saied et al., 1999; Riggio et al., 2010). Milk components, such as fat and protein, and their daily yield are far less frequently studied (Baro et al., 1994) than milk yield. As sheep milk is especially used for the production of cheese, the ovine cheese industry would benefit from an improvement in cheese-making traits (milk coagulation traits, curd firming and syneresis, milk nutrient recovery in curd, and cheese yield). The difficulty of measuring these phenotypes in a large population coupled with their cost limits the number of available studies. In fact, only one study has been carried out to estimate the genetic parameters of cheese yield in ovine species (Othmane et al., 2002a,b), and only one in the bovine species (Bittante et al., 2013a). In the case of milk coagulation and curd firming properties, the situation is different in the 2 species: several studies on genetic parameters have been carried out with dairy cattle, as reviewed by Bittante et al. (2012), whereas no genetic information is available for the small ruminant species.

The traditional single point traits regarding milk coagulation properties (MCP) were set up for the classification of bovine milk and are not particularly suitable for evaluating ovine milk due to its very rapid coagulation and curd firming after rennet addition (Bencini, 2002; Park et al., 2007). New modeling techniques aimed at better describing milk coagulation, curd firming, and syneresis using all the information recorded during a lactodynamographic test have recently proved to be able to better describe the cheese-making ability of sheep milk with respect to traditional traits (Bittante et al., 2014). These new curd firming and syneresis model parameters have been comprehensively studied from a phenotypic point of view by Vacca et al. (2015), but, to our knowledge, the literature contains a dearth of studies investigating the genetic variation of such traits.

Therefore the aims of the present study were to estimate (1) the genetic parameters of milk yield and composition in the Sarda sheep breed; (2) the genetic parameters of traditional single point coagulation properties; (3) the genetic parameters of the new milk coagulation, curd firming, and syneresis model parameters and derived traits; and (4) the phenotypic and genetic correlations among all the aforementioned traits.

\section{MATERIALS AND METHODS}

\section{Animals and Milk Sampling}

The animals and the milk sampling procedures adopted in the present study have been described in detail in a previous study on phenotypic variation in traditional MCP by Pazzola et al. (2014). Briefly, a total of 1,121 ewes enrolled in the flock-book of the Sarda breed and reared on 23 commercial farms were used. Genetic connectedness was taken into consideration in selecting the farms (i.e., the use of AI of the ewes or the exchange of rams and ewes with other farms, or both). Within flocks, ewes were selected to include all the animals genetically connecting the flock with the other selected flocks (daughters of AI or exchanged rams, exchanged ewes), whereas ewes sired by rams with less than 3 or more than 40 daughters in the database of sampled ewes were excluded. Ewes with clinical signs of disease were also excluded.

The farms were evenly distributed over the island of Sardinia, Italy, representing its different environmental conditions and sheep dairy systems. Lactating ewes were pasture fed and received a commercial concentrate supplement during milking and were generally managed following the common semi-extensive and semiintensive methods as described by Carta et al. (2009). Flock classification was based on flock size (Pazzola et al., 2014). The ewes sampled (32 to 82 per flock) were milked by manually operated milking machines twice a day (usually at 0600 and at $1600 \mathrm{~h}$ ) and were sampled once at $140 \pm 42$ DIM. The descriptive statistics of milk yield are shown in Table 1. Pedigree information was supplied by the Flock Book Society of Italian sheep and goat breeders (Associazione Nazionale della Pastorizia) and included ewes with phenotypic records for the investigated traits and all their known ancestors. Each animal with phenotypic records had at least 4 
Table 1. Descriptive statistics of single test-day milk yield, composition, $\mathrm{pH}$, traditional milk coagulation properties (MCP), and curd firming $\left(\mathrm{CF}_{\mathrm{t}}\right)$ model parameters and maximum curd firmness traits $(\mathrm{n}=1,121$ Sarda ewes)

\begin{tabular}{|c|c|c|}
\hline Trait $^{1}$ & Mean & $\mathrm{SD}$ \\
\hline Milk yield, kg/d & 1.47 & 0.84 \\
\hline \multicolumn{3}{|l|}{ Milk composition } \\
\hline Protein, \% & $\begin{array}{l}6.35 \\
5.32\end{array}$ & $\begin{array}{l}1.19 \\
0.65\end{array}$ \\
\hline Casein, $\%$ & 4.14 & 0.54 \\
\hline Acidity, $\mathrm{pH}$ & 6.67 & 0.01 \\
\hline \multicolumn{3}{|l|}{ Traditional MCP } \\
\hline $\mathrm{RCT}, \min$ & 8.01 & 4.91 \\
\hline $\mathrm{k}_{20}, \min$ & 2.00 & 0.78 \\
\hline $\mathrm{a}_{30}, \mathrm{~mm}$ & 52.9 & 13.0 \\
\hline $\mathrm{a}_{45}, \mathrm{~mm}$ & 48.5 & 15.2 \\
\hline $\mathrm{a}_{60}, \mathrm{~mm}$ & 43.5 & 16.6 \\
\hline \multicolumn{3}{|l|}{$\mathrm{CF}_{\mathrm{t}}$ parameter } \\
\hline $\mathrm{RCT}_{\mathrm{eq}}, \min$ & 9.80 & 4.73 \\
\hline $\mathrm{k}_{\mathrm{CF}}, \% / \mathrm{min}$ & 26.3 & 9.4 \\
\hline $\mathrm{k}_{\mathrm{SR}}, \% / \mathrm{min}$ & 0.98 & 0.67 \\
\hline $\mathrm{CF}_{\mathrm{P}}, \mathrm{mm}$ & 62.5 & 9.1 \\
\hline \multicolumn{3}{|l|}{ Maximum CF } \\
\hline $\mathrm{CF}_{\max }, \mathrm{mm}$ & 54.4 & 9.3 \\
\hline$t_{\max }, \min$ & 28.0 & 9.8 \\
\hline
\end{tabular}

${ }^{1} \mathrm{RCT}=$ rennet coagulation time of samples coagulating within 60 min of enzyme addition; $k_{20}=$ curd-firming time of samples reaching $20 \mathrm{~mm}$ of firmness within $60 \mathrm{~min}$ from enzyme addition; $\mathrm{a}_{30}=$ curd firmness at $30 \mathrm{~min}$ after enzyme addition; $\mathrm{a}_{45}=$ curd firmness at 45 min after enzyme addition; $\mathrm{a}_{60}=$ curd firmness at $60 \mathrm{~min}$ after enzyme addition; $\mathrm{RCT}_{\text {eq }}=$ rennet coagulation time estimated using the $\mathrm{CF}_{t}$ equation; $\mathrm{CF}_{\mathrm{P}}=$ asymptotic potential curd firmness; $\mathrm{k}_{\mathrm{CF}}=$ curd firming instant rate constant; $\mathrm{k}_{\mathrm{SR}}=$ syneresis instant rate constant; $\mathrm{CF}_{\max }$ $=$ maximum curd firmness attained within $45 \mathrm{~min} ; \mathrm{t}_{\max }=$ time at attainment of $\mathrm{CF}_{\max }$.

known ancestors in the pedigree data (4,785 records). Sires numbered 725, and of these, 121 had progeny with records in the data set (each sire having between 3 and 40 daughters).

\section{Milk Composition, Coagulation and Curd Firming Properties, and Syneresis}

The analyses for milk composition have been described in a previous study by Pazzola et al. (2014). A MilkoScan FT6000 (Foss Electric, Hillerød, Denmark) was used to analyze the chemical composition (fat, protein, casein, $\mathrm{pH}$ ) of individual milk samples. The descriptive statistics of sheep milk yield and composition are shown in Table 1.

Measurements of traditional MCP were obtained using a Formagraph (Foss Italia, Padua, Italy). For each individual sample, $10 \mathrm{~mL}$ of milk was heated to $35^{\circ} \mathrm{C}$ followed by addition of $200 \mu \mathrm{L}$ of the rennet solution [Hansen Naturen Plus 215 (Pacovis Amrein AG, Bern, Switzerland) was diluted to $1.2 \%$ (wt/vol) in distilled water] to arrive at 0.0513 international milk clotting units/mL of milk. As lactodynamographic analysis continued for $60 \mathrm{~min}$ after rennet addition, the traditional coagulation single point traits (McMahon and Brown, 1982) were recorded: rennet coagulation time (RCT, min); curd firming time until $20 \mathrm{~mm}$ curd firmness ( $\mathbf{k}_{\mathbf{2 0}}$, min); and curd firmness (CF) recorded $30 \mathrm{~min}$ as well as 45 and $60 \min \left(\mathbf{a}_{\mathbf{3 0}}, \mathbf{a}_{45}\right.$, and $\mathbf{a}_{60}$, respectively) after rennet addition. The descriptive statistics of traditional single point MCP are shown in Table 1.

In addition, during the lactodynamographic test, all individual $\mathrm{CF}$ records (one every 15 s, i.e., 240 records for each individual milk sample) were saved to be modeled according to the 4-parameter model described by Bittante et al. (2013b):

$$
\mathrm{CF}_{\mathrm{t}}=\mathrm{CF}_{\mathrm{P}} \times\left(1-\mathrm{e}^{-\mathrm{k}_{\mathrm{CF}} \times\left(\mathrm{t}-\mathrm{RCT}_{\mathrm{eq}}\right)}\right) \times \mathrm{e}^{-\mathrm{k}_{\mathrm{SR}} \times\left(\mathrm{t}-\mathrm{RCT}_{\mathrm{eq}}\right)},
$$

where $\mathrm{CF}_{\mathrm{t}}$ is the curd firmness at time $\mathrm{t}(\mathrm{mm}), \mathrm{CF}_{\mathrm{P}}$ is the asymptotic potential maximum value of curd firmness at infinite time $(\mathrm{mm}), \mathrm{k}_{\mathrm{CF}}$ is the curd-firming instant rate constant $\left(\% \times \mathrm{min}^{-1}\right), \mathrm{k}_{\mathrm{SR}}$ is the curd syneresis instant rate constant $\left(\% \times \mathrm{min}^{-1}\right)$, and $\mathrm{RCT}_{\mathrm{eq}}$ is the rennet coagulation time estimated by the model (min). Two more traits were derived from the model equations for each individual milk sample: $\mathrm{CF}_{\max }$, that is, the maximum $\mathrm{CF}$ value predicted by the $\mathrm{CF}_{\mathrm{t}}$ equation (in $\mathrm{mm}$ ); and $\mathbf{t}_{\max }$, that is, the time interval from rennet addition to attaining $\mathrm{CF}_{\max }$ (min). The $\mathrm{CF}_{\mathrm{t}}$ model is illustrated in Figure 1 and the descriptive statistics of the $\mathrm{CF}_{\mathrm{t}}$ model parameters and derived traits are shown in Table 1.

\section{Statistical Analyses}

Modeling the CF of Individual Milk Samples. In a previous phenotypic analysis (Vacca et al., 2015) on the same data set, the results from the modeling of individual lactodynamographic patterns differed from those found with ewes of Alpine breeds (Bittante et al., 2014). In fact, almost $5 \%$ of milk samples were characterized by nonconvergence of the $\mathrm{CF}_{\mathrm{t}}$ equations, almost $5 \%$ yielded a very high value for $\mathrm{k}_{\mathrm{SR}}$, and $18 \%$ yielded no estimable $\mathrm{k}_{\mathrm{SR}}$. Examples of these patterns are illustrated in Vacca et al. (2015). To avoid these problems with convergence and estimation, the procedure was modified: (1) to include CF measurements until $45 \mathrm{~min}$ from the addition of rennet (180 records for each individual milk sample, one every $15 \mathrm{~s}$ ); (2) to calculate, on the basis of a preliminary analysis of relationships among traits, $\mathrm{CF}_{\mathrm{P}}$ on the basis of the highest $\mathrm{CF}$ recorded augmented by $8 \mathrm{~mm}$. The other $3 \mathrm{CF}_{\mathrm{t}}$ model parameters $\left(\mathrm{RCT}_{\mathrm{eq}}, \mathrm{k}_{\mathrm{CF}}\right.$, and $\left.\mathrm{k}_{\mathrm{SR}}\right)$ were estimated through curvilinear regression using the nonlinear procedure (PROC NLIN) of the SAS software (2001, SAS Insti- 


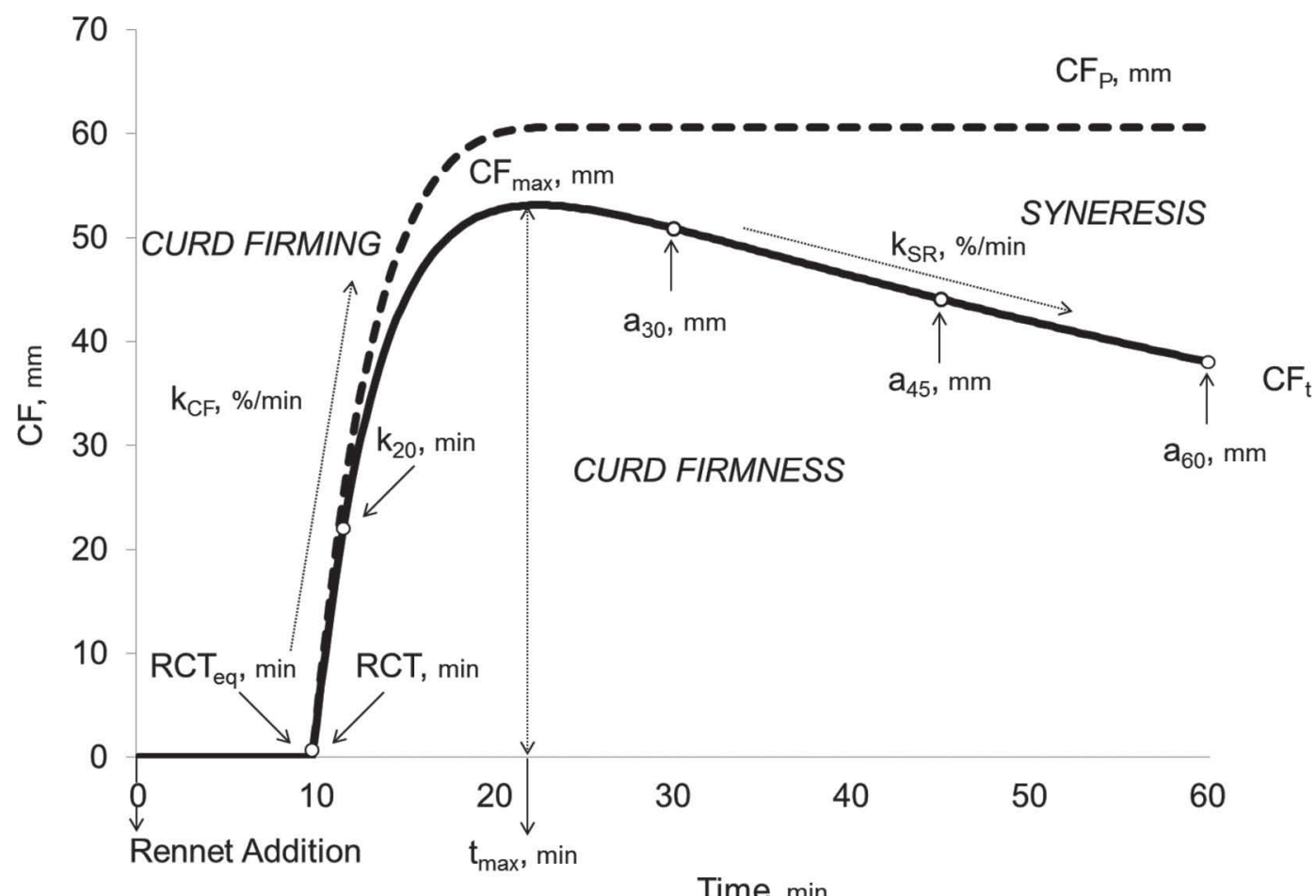

Figure 1. Modeling prolonged observations of curd firmness at time t model parameters. The solid black line represents the modeling of frequent observations of curd firmness $(\mathrm{CF}$, one observation every $15 \mathrm{~s})$ at time $\mathrm{t}\left(\mathrm{CF}_{\mathrm{t}}\right)$. The model parameters are $\mathrm{RCT}_{\mathrm{eq}}=$ rennet coagulation time from enzyme addition (min) estimated using the $\mathrm{CF}_{\mathrm{t}}$ equation; $\mathrm{CF}_{\mathrm{P}}=$ potential asymptotical curd firmness $(\mathrm{mm}) ; \mathrm{k}_{\mathrm{CF}}=\mathrm{curd}-$ firming rate constant $\left(\% \times \min ^{-1}\right) ; \mathrm{k}_{\mathrm{SR}}=$ syneresis rate constant $\left(\% \times \min ^{-1}\right)$. Two maximum $\mathrm{CF}$ traits are calculated from the model equation: $\mathrm{CF}_{\max }=$ maximum curd firmness $(\mathrm{mm})$; and $\mathrm{t}_{\max }=$ time to $\mathrm{CF}_{\max }(\mathrm{min})$. The open circles represent traditional single point coagulation properties. $\mathrm{RCT}$ $=$ the time from enzyme addition to the last point below $1 \mathrm{~min}, \mathrm{~min} ; \mathrm{k}_{20}=$ the difference between the time to the first point greater than 20 $\mathrm{mm} \mathrm{CF}$ and $\mathrm{RCT}$, min; and $\mathrm{a}_{30}, \mathrm{a}_{45}, \mathrm{a}_{60}=$ the $\mathrm{CF}$ value recorded 30, 45, and 60 min after enzyme addition, mm (from Dadousis et al., 2016).

tute Inc., Cary, NC). The parameters of each individual equation were estimated using the Marquardt iterative method (350 iterations and a $10^{-5}$ level of convergence) according to Bittante (2011). Using this procedure only one noncoagulating milk sample was found, whereas no nonconvergent samples nor samples with very high nonestimable $\mathrm{k}_{\mathrm{SR}}$ were found.

Genetic Analysis. Nongenetic effects analyzed in a previous phenotypic study on the same data set (Vacca et al., 2015) were taken into account in estimating the genetic parameters of $\mathrm{MCP}, \mathrm{CF}_{\mathrm{t}}$, test-day milk yield, composition, and acidity. Briefly, the model accounted for the effects of flock-date (23 levels), DIM (class 1: 61 to 80 d; class 2: $81-100$; class 3: 101-120; class 4: 121-140; class 5: 141-160; class 6: 161-180; class 7: 181-200; and class 8: $>200 \mathrm{~d}$ ), parity of the ewes (1 to 5 or more), and the measuring unit of the coagulation meter (10 levels, based on the position of the individual pendulum).

Univariate and bivariate sire models were fitted to estimate (co)variance components for the traits of concern. The model assumed for $\mathrm{MCP}, \mathrm{CF}_{\mathrm{t}}$, test-day milk yield, and composition was

$$
\mathbf{y}=\mathbf{X b}+\mathbf{Z}_{1} \mathbf{f}+\mathbf{Z}_{2} \mathbf{s}+\mathbf{e}
$$

where $\mathbf{y}$ is a vector of records for traits 1 and $2 ; \mathbf{X}, \mathbf{Z}_{1}$, and $\mathbf{Z}_{2}$ are appropriate incidence matrices for systematic effects in $\mathbf{b}$, flock/date effects in $\mathbf{f}$, and sire genetic effects in $\mathbf{s}$, respectively; and $\mathbf{e}$ is a vector of random residuals. (Co)variance components and related parameters were estimated using a Bayesian approach and Markov-chain Monte Carlo methods (Sorensen and Gianola, 2002). All traits were taken as continuous variables, and their values were assumed to be sampled from the following multivariate normal (MVN) distribution:

$$
p(\mathbf{y} \mid \mathbf{b}, \mathbf{f}, \mathbf{s}, \mathbf{R}) \sim \operatorname{MVN}\left(\mathbf{X b}+\mathbf{Z}_{1} \mathbf{f}+\mathbf{Z}_{2} \mathbf{s}, \mathbf{I} \otimes \mathbf{R}\right),
$$

where $\mathbf{y}, \mathbf{b}, \mathbf{f}, \mathbf{s}, \mathbf{X}, \mathbf{Z}_{1}$, and $\mathbf{Z}_{2}$ are as defined above; $\mathbf{R}$ is a $2 \times 2$ matrix of residual (co)variances; and $\mathbf{I}$ is an identity matrix of appropriate order. The data were properly ordered within the vectors, and vectors $\mathbf{s}$ and $\mathbf{f}$ contained the effects of both traits individual by individual. 
In a Bayesian setting, we assumed

$$
\begin{gathered}
p(\mathbf{s} \mid \mathbf{G}) \sim \operatorname{MVN}(0, \mathbf{A} \otimes \mathbf{G}), \text { and } \\
p(\mathbf{f} \mid \mathbf{F}) \sim \operatorname{MVN}(0, \mathbf{I} \otimes \mathbf{F}),
\end{gathered}
$$

where $\mathbf{G}$ is a $2 \times 2$ sire (co)variance matrix, $\mathbf{A}$ is the additive genetic relationship matrix among sires, $\mathbf{F}$ is a $2 \times 2$ (co)variance matrix for flock/date effects, and $\mathbf{I}$ is the identity matrix of the same order as the number of levels of flock/date effects. Flat priors were assumed for the effects in $\mathbf{b}$, as well as for $\mathbf{G}, \mathbf{F}$, and $\mathbf{R}$. Marginal posterior distributions of all unknowns were estimated using the Gibbs sampling algorithm. The TM program (http://snp.toulouse.inra.fr/ alegarra) was used for all Gibbs sampling procedures. After some preliminary analysis, chains of 850,000 samples were used, with a burn-in period of 50,000. Subsequently, one in every 200 successive samples was retained.

Across-flock heritability $\left(h_{a f}^{2}\right)$ was computed as

$$
h_{a f}^{2}=\frac{4 \sigma_{\mathrm{s}}^{2}}{\sigma_{\mathrm{s}}^{2}+\sigma_{\mathrm{f}}^{2}+\sigma_{\mathrm{e}}^{2}},
$$

where $\sigma_{\mathrm{s}}^{2}, \sigma_{\mathrm{f}}^{2}$, and $\sigma_{\mathrm{e}}^{2}$ are sire, flock-date, and residual variances, respectively.

Intra-flock heritability $\left(h_{i f}^{2}\right)$ was computed as

$$
h_{i f}^{2}=\frac{4 \sigma_{\mathrm{s}}^{2}}{\sigma_{\mathrm{s}}^{2}+\sigma_{\mathrm{e}}^{2}},
$$

where $\sigma_{\mathrm{s}}^{2}$ and $\sigma_{\mathrm{e}}^{2}$ are sire and residual variances, respectively.

The proportion of the total variance caused by flockdate $\left(h_{\text {flock }}\right)$ was computed as

$$
h_{f l o c k}=\frac{\sigma_{\mathrm{f}}^{2}}{\sigma_{\mathrm{s}}^{2}+\sigma_{\mathrm{f}}^{2}+\sigma_{\mathrm{e}}^{2}} .
$$

Here, $\sigma_{\mathrm{s}}^{2}, \sigma_{\mathrm{f}}^{2}$, and $\sigma_{\mathrm{e}}^{2}$ were additive sire, flock-date, and residual variances, respectively.

The additive genetic correlations $\left(r_{a}\right)$ were computed as

$$
r_{a}=\frac{\sigma_{\mathrm{s} 1, \mathrm{~s} 2}}{\sigma_{\mathrm{s} 1} \cdot \sigma_{\mathrm{s} 2}}
$$

where $\sigma_{\mathrm{s} 1, \mathrm{~s} 2}$ was the additive sire covariance between traits 1 and 2, and $\sigma_{\mathrm{s} 1}$ and $\sigma_{\mathrm{s} 2}$ were the sire genetic standard deviations for traits 1 and 2, respectively.
The phenotypic correlations $\left(r_{p}\right)$ were computed as

$$
r_{p}=\frac{\sigma_{\mathrm{p} 1, \mathrm{p} 2}}{\sigma_{\mathrm{p} 1} \cdot \sigma_{\mathrm{p} 2}},
$$

where $\sigma_{\mathrm{p} 1, \mathrm{p} 2}$ was the phenotypic covariance between traits 1 and 2, and $\sigma_{\mathrm{p} 1}$ and $\sigma_{\mathrm{p} 2}$ were the phenotypic standard deviations for traits 1 and 2 , respectively.

\section{RESULTS AND DISCUSSION}

\section{Variance Components and Heritability of Milk Yield and Composition}

The average values and the effects of farm, and parity and DIM of ewes on milk yield and composition have been described in detail and discussed in a previous study on the same data set (Pazzola et al., 2014).

Point estimates (mean of the marginal posterior density of the parameter) of variance components, intraflock and across-flock heritabilities, and the contribution of the effect of flock-date on the phenotypic variation in all investigated traits are shown in Table 2. Milk yield (of a single test-day) of the multiparous Sarda ewes exhibited a very high effect of individual flock/ date representing almost $75 \%$ of the total phenotypic variance of the trait (Table 2), which explained why heritability measured across-flocks was low $\left(h_{a h}^{2}=\right.$ $0.040)$, whereas within flocks it was moderate $\left(h_{i h}^{2}=\right.$ 0.158). As expected, the heritability estimate for milk production over the whole of lactation was greater with primiparous and multiparous ewes of the Sarda sheep breed (0.29; Carta et al., 1998), and even greater with only primiparous ewes (0.38; Sanna et al., 2002) compared with the estimate for our single test-day milk yield.

The heritability estimate for the Churra sheep breed was found to be 0.15 for test-day milk yield (Othmane et al., 2002b) and 0.26 for the whole of lactation milk yield (Othmane et al., 2002a). With the same breed, de la Fuente et al. (2011) found very different heritability estimates of test-day milk yield in primiparous and multiparous ewes ( 0.20 and 0.06 , respectively), whereas no information is given on the effect of flock/date variance.

Regarding milk quality traits, the contribution of flock/date variance to total phenotypic variance was much smaller than for milk yield (30 to $35 \%$, Table 2). Consequently, the difference between the across-flock and intra-flock heritability estimates was smaller than in the case of milk yield. The heritabilities of milk fat, protein, and casein were very similar $(0.267$ to 0.283$)$ and not very different from the majority of published 
estimates (Carta et al., 2009), with the exception of the lower estimates of milk fat found with Spanish breeds (de la Fuente et al., 2011). The heritability of milk pH was slightly lower than that of milk components (0.199).

\section{Variance Component and Heritability of Traditional Milk Coagulation Properties}

The average values and the effects of farm, parity, and DIM of lactating ewes have been described in detail and discussed in a previous study on the same data set (Pazzola et al., 2014). The traditional single point MCP were characterized by medium variability among flocks/dates: about $15 \%$ of total variance for $\mathrm{RCT}$ and $\mathrm{k}_{20}$, and 33 to $43 \%$ for CF measured 30 to $60 \mathrm{~min}$ after rennet addition (Table 2). These values were much greater than those found in the bovine species. In dairy cows, in fact, the herd effect represents a small proportion of the phenotypic variance of RCT and $\mathrm{a}_{30}$ (below 10\%, Tyrisevä et al., 2003). More recently, Cecchinato et al. (2013) found a greater incidence of herd variance on phenotypic variance, peaking at $18 \%$ for $\mathrm{a}_{45}$.

Marginal posterior distributions of the intra-flock heritability for traditional MCP are depicted in Figure 2a. Intra-flock heritability was 0.188 in the case of RCT of sheep milk (Table 2). No other estimate is available for ovine species, but this value was equal to the average value of several estimates reviewed by Bittante et al. (2012). The heritability estimate of $\mathrm{a}_{30}$ of sheep milk was almost half of both the RCT value (0.138) in the same species and the average value found in the bovine species for the same trait $(0.27 \pm 0.11)$. The other traditional traits $\left(\mathrm{k}_{20}, \mathrm{a}_{45}\right.$, and $\left.\mathrm{a}_{60}\right)$ recorded in sheep milk were characterized by even smaller heritabilities (0.112 to 0.095 Table 2), about half those of the bovine species. The main reason is probably that traditional lactodynamographic traits were set up for cow milk, and as discussed by Vacca et al. (2015), they do not adequately represent the curd firming process of sheep milk after coagulation, which is very rapid, has a high maximum $\mathrm{CF}$ value, and shows evidence of a variable, sometimes rapid, syneresis of curd.

With the exceptions of the expected high phenotypic and genetic correlations between the 3 measures of $\mathrm{CF}$ (Table 3), the correlations between the other traditional coagulation properties were similar to or smaller than those found in bovine species (Cecchinato et al., 2013). Also in this case, the reason may be the short coagulation time, the rapid increase in the curd firming value, and the presence of variable degrees of syneresis,

Table 2. Estimates of sire variance $\left(\sigma_{\mathrm{s}}^{2}\right)$, flock-date variance $\left(\sigma_{\mathrm{f}}^{2}\right)$, residual variance $\left(\sigma_{\mathrm{e}}^{2}\right)$, across flock heritability $\left(h_{a f}^{2}\right)$, intra-flock heritability $\left(h_{i f}^{2}\right)$, and flock-date variance as proportions of total variance $\left(h_{\text {flock }}\right)$ for single test-day milk yield, composition, $\mathrm{pH}$, traditional milk coagulation properties $(\mathrm{MCP})$, and curd firming $\left(\mathrm{CF}_{\mathrm{t}}\right)$ model parameters and maximum curd firmness traits

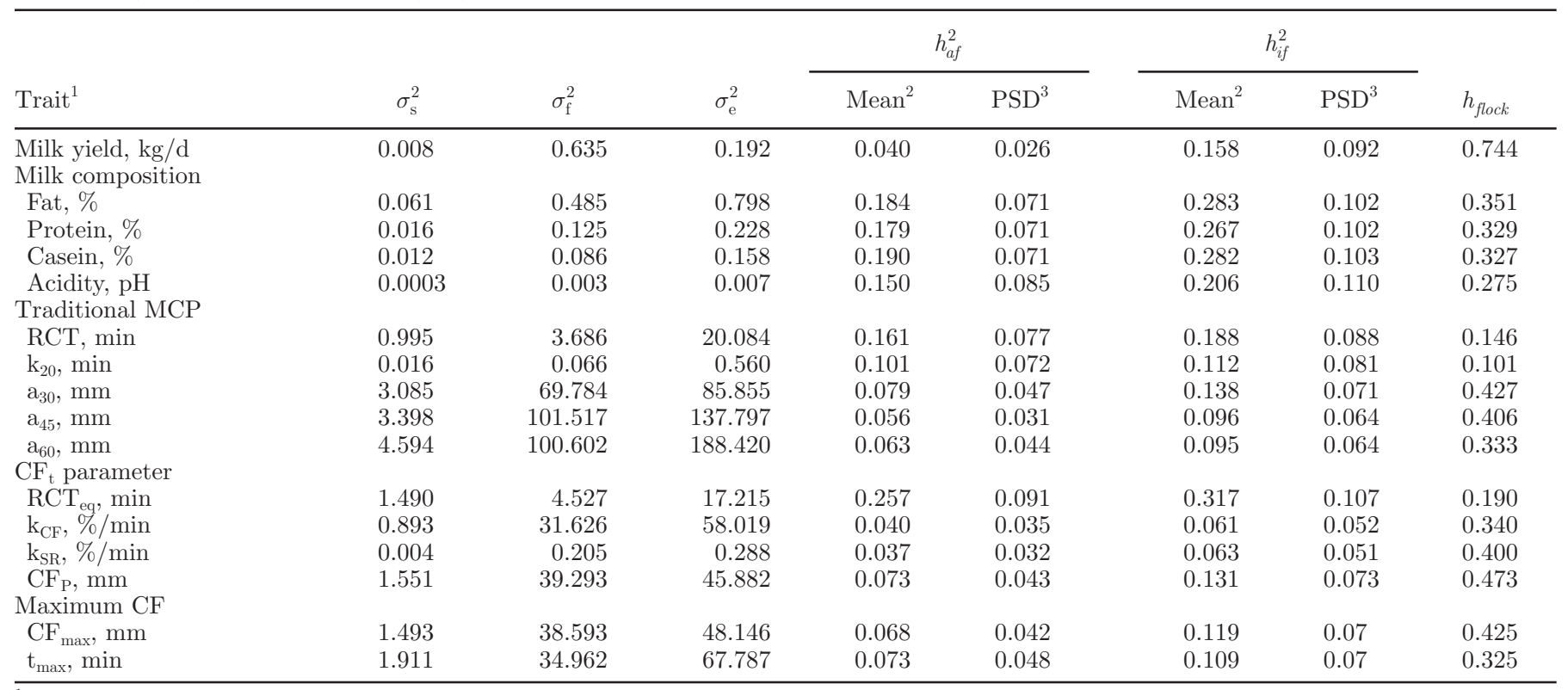

${ }^{1} \mathrm{RCT}=$ rennet coagulation time of samples coagulating within $60 \mathrm{~min}$ of enzyme addition; $\mathrm{k}_{20}=$ curd-firming time of samples reaching $20 \mathrm{~mm}$ of firmness within 60 min from enzyme addition; $\mathrm{a}_{30}=$ curd firmness at $30 \mathrm{~min}$ after enzyme addition; $\mathrm{a}_{45}=$ curd firmness at 45 min after enzyme addition; $\mathrm{a}_{60}=$ curd firmness at 60 min after enzyme addition; $\mathrm{RCT}_{\mathrm{eq}}=$ rennet coagulation time estimated using the $\mathrm{CF}_{\mathrm{t}}$ equation; $\mathrm{CF}_{\mathrm{P}}$ $=$ asymptotic potential curd firmness; $\mathrm{k}_{\mathrm{CF}}=$ curd firming instant rate constant; $\mathrm{k}_{\mathrm{SR}}=$ syneresis instant rate constant; $\mathrm{CF}_{\max }=$ maximum curd firmness attained within 45 min; $\mathrm{t}_{\max }=$ time at attainment of $\mathrm{CF}_{\max }$.

${ }^{2}$ Mean: mean of the marginal posterior density of the parameter.

${ }^{3} \mathrm{PSD}$ : posterior standard deviation. 
meaning $\mathrm{CF}$ at 30 min or later is often measured in the decreasing part of the CF curve.

\section{Variance Component and Heritability of Curd Firming Modeling Parameters and Derived Traits}

The modeling of all 180 information points obtained from the lactodynamograph for each individual sheep milk sample is described in detail and discussed by Vacca et al. (2015).

The $\mathrm{CF}_{\mathrm{P}}$ parameter is conceptually independent from test duration and, unlike $\mathrm{a}_{30}$, is not intrinsically dependent on RCT. The parameter $\mathrm{k}_{\mathrm{CF}}$ is assumed to increase $\mathrm{CF}$ toward the $\mathrm{CF}_{\mathrm{P}}$ asymptotic value, whereas $\mathrm{k}_{\mathrm{SR}}$ is assumed to decrease CF toward a null asymptotic value. In the initial phase of the test, the first rate constant prevails over the second, and the $\mathrm{CF}_{\mathrm{t}}$ increases to a point in time $\left(t_{\max }\right)$ where the effects of the 2 parameters are equal but opposite in sign and $\mathrm{CF}_{\mathrm{t}}$ has reached its maximum level $\left(\mathrm{CF}_{\max }\right)$. Thereafter, $\mathrm{CF}_{\mathrm{t}}$ begins to decrease and tends toward a null value because of the effect of curd syneresis and the corresponding expulsion of whey. This pattern on the $\mathrm{CF}_{\mathrm{t}}$ curve was much more accelerated for ovine than for bovine milk (Bittante et al., 2012, 2015). The $\mathrm{RCT}_{\text {eq }}$ parameter conceptually corresponds to the traditional RCT measure, but it is estimated by the model using all available data.

Marginal posterior distributions of the intra-flock heritability for $\mathrm{CF}_{t}$ model parameters and maximum $\mathrm{CF}$ traits are depicted in Figure 2b. The intra-flock heritability of $\mathrm{RCT}_{\mathrm{eq}}$ was much greater than that of the corresponding traditional single point value (0.317 vs. 0.188 , respectively; Table 2). This was due to both the greater sire variance and the smaller residual variance of the equation parameter, indication of its superior repeatability over the single point measure. The incidence of flock variance on total variance for the other equation parameters and derived traits was similar to that observed for traditional coagulation properties (Table 2), nor were heritability estimates greatly different. In particular, the 2 instant rate constants $\left(\mathrm{k}_{\mathrm{CF}}\right.$ and $\mathrm{k}_{\mathrm{SR}}$ ) had modest heritability values. The overall heritabilities of individual equation parameters in the bovine species were not much different from those obtained in the present study (Cecchinato et al., 2015), with the exceptions of the smaller values for $\mathrm{RCT}_{\mathrm{eq}}$ and $\mathrm{CF}_{\mathrm{P}}$, and greater values for $\mathrm{k}_{\mathrm{CF}}$ and the 2 derived traits $\left(\mathrm{CF}_{\max }\right.$ and $\left.\mathrm{t}_{\max }\right)$.

The additive genetic correlations among all $\mathrm{CF}_{\mathrm{t}}$ parameters and derived traits were intermediate, with the exception of the smaller values observed for those between $\mathrm{k}_{\mathrm{CF}}$ and $\mathrm{CF}_{\mathrm{P}}$ and $\mathrm{CF}_{\max }$ (Table 3). The phenotypic and genetic correlations of traditional single point traits with the equation parameters and derived traits
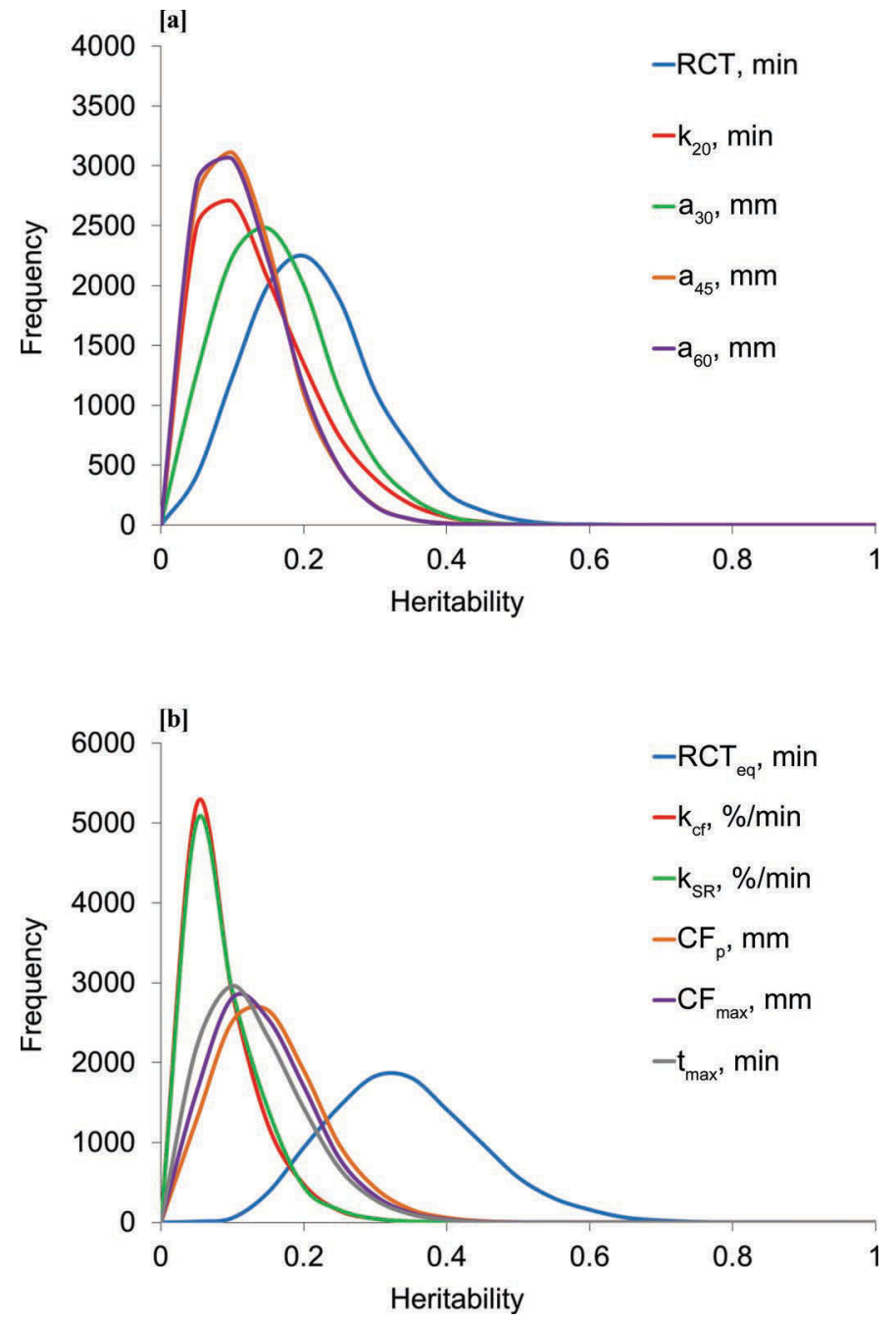

Figure 2. Marginal posterior distributions of the intra-flock heritability for traditional milk coagulation properties (a) and curd firming $\left(\mathrm{CF}_{t}\right)$ model parameters and maximum curd firmness traits (b). RCT $=$ rennet coagulation time of samples coagulating within $60 \mathrm{~min}$ from enzyme addition; $\mathrm{k}_{20}=$ curd-firming time of samples reaching $20 \mathrm{~mm}$ of firmness within $60 \mathrm{~min}$ from enzyme addition; $\mathrm{a}_{30}=$ curd firmness at $30 \mathrm{~min}$ after enzyme addition; $\mathrm{a}_{45}=$ curd firmness at $45 \mathrm{~min}$ after enzyme addition; $\mathrm{a}_{60}=$ curd firmness at 60 min after enzyme addition; $\mathrm{RCT}_{\text {eq }}=$ rennet coagulation time estimated using the $\mathrm{CF}_{\mathrm{t}}$ equation; $\mathrm{CF}_{\mathrm{P}}=$ asymptotic potential curd firmness; $\mathrm{k}_{\mathrm{CF}}=$ curd firming instant rate constant; $\mathrm{k}_{\mathrm{SR}}=$ syneresis instant rate constant; $\mathrm{CF}_{\max }=$ maximum curd firmness achieved within $45 \mathrm{~min} ; \mathrm{t}_{\max }=$ time at achievement of $\mathrm{CF}_{\max }$.

were highly variable and contributed to describing their intrinsic meaning more clearly.

\section{Phenotypic and Additive Genetic Correlations Between Milk Yield and Composition and Lactodynamographic Traits}

The phenotypic correlations between milk yield and composition and lactodynamographic traits were gen- 
Table 3. Estimates of phenotypic (above diagonal) and additive genetic (below diagonal) correlations between traditional milk coagulation properties $(\mathrm{MCP})$ and curd firming $\left(\mathrm{CF}_{\mathrm{t}}\right)$ model parameters, and derived maximum curd firmness traits ${ }^{1}$

\begin{tabular}{|c|c|c|c|c|c|c|c|c|c|c|c|}
\hline Trait $^{2}$ & \multicolumn{5}{|c|}{ Traditional MCP } & \multicolumn{4}{|c|}{$\mathrm{CF}_{\mathrm{t}}$ parameter } & \multicolumn{2}{|c|}{ Maximum CF } \\
\hline $\mathrm{RCT}$, min & & 0.69 & -0.12 & 0.02 & 0.01 & 0.99 & -0.40 & -0.17 & -0.21 & -0.21 & 0.44 \\
\hline $\mathrm{k}_{20}, \min$ & 0.75 & & -0.49 & -0.32 & -0.28 & 0.75 & -0.24 & 0.14 & -0.62 & -0.62 & 0.12 \\
\hline $\mathrm{a}_{30}, \mathrm{~mm}$ & -0.55 & -0.72 & & 0.90 & 0.79 & -0.21 & -0.61 & -0.83 & 0.90 & 0.90 & 0.63 \\
\hline $\mathrm{a}_{45}, \mathrm{~mm}$ & 0.01 & -0.41 & 0.91 & & 0.93 & -0.06 & -0.76 & -0.92 & 0.84 & 0.84 & 0.74 \\
\hline \multicolumn{12}{|l|}{$\mathrm{CF}_{\mathrm{t}}$ parameter } \\
\hline $\mathrm{RCT}_{\mathrm{eq}}, \min$ & 0.99 & 0.82 & -0.53 & -0.08 & 0.09 & & -0.38 & -0.11 & -0.32 & -0.32 & 0.20 \\
\hline $\mathrm{k}_{\mathrm{CF}}, \% / \mathrm{min}$ & -0.16 & -0.59 & -0.24 & -0.51 & -0.67 & -0.46 & & 0.88 & -0.37 & -0.37 & -0.80 \\
\hline $\mathrm{k}_{\mathrm{SR}}, \% / \min$ & 0.45 & 0.25 & -0.78 & -0.86 & -0.84 & 0.32 & 0.73 & & -0.65 & -0.65 & -0.71 \\
\hline $\mathrm{CF}_{\mathrm{P}}, \mathrm{mm}$ & -0.23 & -0.69 & 0.91 & 0.93 & 0.80 & -0.39 & -0.01 & -0.62 & & $1.00^{3}$ & 0.59 \\
\hline \multicolumn{12}{|l|}{ Maximum CF } \\
\hline $\mathrm{CF}_{\max }, \mathrm{mm}$ & -0.22 & -0.69 & 0.91 & 0.92 & 0.78 & -0.38 & 0.01 & -0.64 & $1.00^{3}$ & & 0.58 \\
\hline $\mathrm{t}_{\max }, \min$ & 0.74 & 0.37 & 0.35 & 0.69 & 0.76 & 0.77 & -0.72 & -0.40 & 0.52 & 0.51 & \\
\hline
\end{tabular}

${ }^{1}$ Mean of the marginal posterior density of the correlation; bold indicates additive genetic correlations with $\geq 90 \%$ of posterior probability accumulated above 0 (positive estimates) or below 0 (negative estimates).

${ }^{2} \mathrm{RCT}=$ rennet coagulation time of samples coagulating within $60 \mathrm{~min}$ from enzyme addition; $\mathrm{k}_{20}=$ curd-firming time of samples reaching 20 $\mathrm{mm}$ of firmness within $60 \mathrm{~min}$ from enzyme addition; $\mathrm{a}_{30}=$ curd firmness at 30 min after enzyme addition; $\mathrm{a}_{45}=$ curd firmness at 45 min after enzyme addition; $\mathrm{a}_{60}=$ curd firmness at 60 min after enzyme addition; $\mathrm{RCT}_{\mathrm{eq}}=$ rennet coagulation time estimated using the $\mathrm{CF}_{\mathrm{t}}$ equation; $\mathrm{CF}_{\mathrm{P}}$ $=$ asymptotic potential curd firmness; $\mathrm{k}_{\mathrm{CF}}=$ curd firming instant rate constant; $\mathrm{k}_{\mathrm{SR}}=$ syneresis instant rate constant; $\mathrm{CF}_{\max }=$ maximum curd firmness attained within $45 \mathrm{~min} ; \mathrm{t}_{\max }=$ time at attainment of $\mathrm{CF}_{\max }$.

${ }^{3}$ The $\mathrm{CF}_{\mathrm{P}}$ parameter is estimated from the measured maximum value of $\mathrm{CF}$, which is very similar to $\mathrm{CF}_{\max }$ yielded by the model equation, so that the phenotypic and genetic correlation between the 2 traits is almost 1 .

erally modest, with a few notable exceptions (Table 4) regarding the protein and casein contents of milk, which affected both RCT unfavorably, but tended to have a positive effect on all the other $\mathrm{CF}_{\mathrm{t}}$ parameters and derived traits (instant rate constants excluded). An increase in $\mathrm{pH}$ was associated with unfavorable effects on both traditional and modeled coagulation and curd firming traits, especially both coagulation times, but not curd syneresis. With regard to bovine milk, similar scarce phenotypic correlations have been observed with milk yield and fat content; protein and casein contents are favorably correlated with $\mathrm{a}_{30}$, but almost independent of RCT, whereas $\mathrm{pH}$ is unfavorably correlated with both traits, as reviewed by Bittante et al. (2012).

Moving to the additive genetic correlations (Table 4), it should be noted that they are generally greater than the phenotypic correlations. Milk yield exerts a negative effect on $\mathrm{CF}$ traits $\left(\mathrm{a}_{30}, \mathrm{a}_{45}, \mathrm{a}_{60}, \mathrm{CF}_{\mathrm{P}}\right.$, and $\left.\mathrm{CF}_{\max }\right)$, but a favorable effect on velocity traits $\left(\mathrm{k}_{20}, \mathrm{k}_{\mathrm{CF}}, \mathrm{k}_{\mathrm{SR}}\right.$, $\left.\mathrm{t}_{\max }\right)$.

In the bovine species, where coagulation time is longer and maximum $\mathrm{CF}$ is reached after $30 \mathrm{~min}$, the increase in daily milk yield is not genetically associated with RCT (as in sheep milk), nor with CF (unlike sheep milk).

Unlike bovine milk, the fat content of sheep milk was found to be genetically positively associated with all measures of CF: traditional $\mathrm{a}_{30}, \mathrm{a}_{45}$, and $\mathrm{a}_{60}$, and especially $\mathrm{CF}_{\mathrm{t}}$ traits $\mathrm{CF}_{\mathrm{P}}, \mathrm{CF}_{\max }$, and $\mathrm{t}_{\max }$ (Table 4).
The results regarding the protein and casein contents of sheep milk were almost the opposite of those previously found for cow milk. The RCT is not genetically correlated with protein and casein contents in cattle, but was very unfavorably correlated with them in sheep. The explanation could lie in the fact that in practice similar or lower quantities of rennet are used in making sheep cheese than cow cheese, probably because of the rapid coagulation of sheep milk and despite its greater protein content. Consequently, it could be hypothesized that the quantity of rennet could become a limiting factor with the increasing protein content of sheep milk. Curd firmness $\left(a_{30}\right)$ is genetically favorably related to protein and casein contents in bovine milk, but it is almost independent in ovine milk $\left(\mathrm{a}_{30}, \mathrm{a}_{45}, \mathrm{a}_{60}\right)$. The genetic associations were more evident with $\mathrm{CF}_{\mathrm{t}}$ modeling, in particular the positive association of protein and casein contents with both instant rate constants $\left(\mathrm{k}_{\mathrm{CF}}\right.$ and $\mathrm{k}_{\mathrm{SR}}$ ) and with $\mathrm{t}_{\max }$.

It worth noting that in ovine as in bovine species, $\mathrm{pH}$ is the milk trait most genetically correlated-unfavorably — with milk technological traits.

\section{Genetic Improvement of Sheep for Milk Technological Properties}

The large additive genetic variance estimated in the study for traditional MCP, $\mathrm{CF}_{\mathrm{t}}$, and derived traits suggests this variation could be exploited in dairy sheep 
breeding programs aimed at genetically improving milk coagulation, curd firming, and syneresis abilities. Direct selection for these technological parameters might be the most effective selection strategy, but populationwide recording of individual phenotypes is not feasible due to limitations imposed by features of the lactodynamographic analysis. Aside from this, the scarce use of AI makes it difficult to use the breeding strategies typical of dairy cattle.

A valuable alternative tested on dairy cattle populations is the use of molecular genetics. The relationships between milk protein genetic variants and MCP and cheese yield have been known for decades (Cecchinato et al., 2012). More recently, coagulation properties have also been studied using genome-wide techniques with interesting results (Tyrisevä et al., 2008; Gregersen et al., 2015; Dadousis et al., 2016). A genome-wide approach has not yet been used in the ovine species, but here, too, the cost:revenue ratio is much less favorable than in dairy cattle.

\section{CONCLUSIONS}

Genetic parameters for technological properties, milk yield, and composition were estimated for Sarda dairy sheep. Both traditional MCP and curd firming model parameters and derived traits exhibited exploitable genetic variation. The modeling of curd firming yielded better results in terms of genetic parameters and seemed more useful than traditional MCP in describing the coagulation, curd firming, and syneresis of ovine milk. Moreover, the additive genetic correlations with phenotypes selected under a common selection objective revealed a contradictory situation: unfavorable effects of protein and casein contents on RCT, and often unfavorable effects of milk yield and favorable effects of milk fat content on CF. A direct genetic improvement in milk technological properties in dairy sheep through traditional selection schemes does not seem to be feasible, but future research is necessary to discover the genetic improvement achievable through alternative methods such as Fourier transform infrared spectroscopy (provided that routine acquisition of spectra from individual milk samples is already performed) and genomic selection.

\section{ACKNOWLEDGMENTS}

This research was supported by a grant from the Fondazione di Sardegna (Sardinia Foundation, Italy). The authors thank the farmers for giving access to their flocks, the A.I.P.A./A.P.A.s (Provincial Livestock Farmers' Associations) of Cagliari, Nuoro, Sassari, and Oristano for their support in sample collection, and A.R.A. Sardegna (Regional Livestock Farmers' Association of Sardinia) for support in milk analysis. The authors also thank the Associazione Nazionale della Pastorizia (Asso.Na.Pa) for providing pedigree data.

Table 4. Estimates of phenotypic $\left(r_{p}\right)$ and additive genetic $\left(r_{a}\right)$ correlations between single test-day milk yield and composition and traditional milk coagulation properties (MCP) and curd firming $\left(\mathrm{CF}_{\mathrm{t}}\right)$ model parameters and maximum curd firmness traits ${ }^{1}$

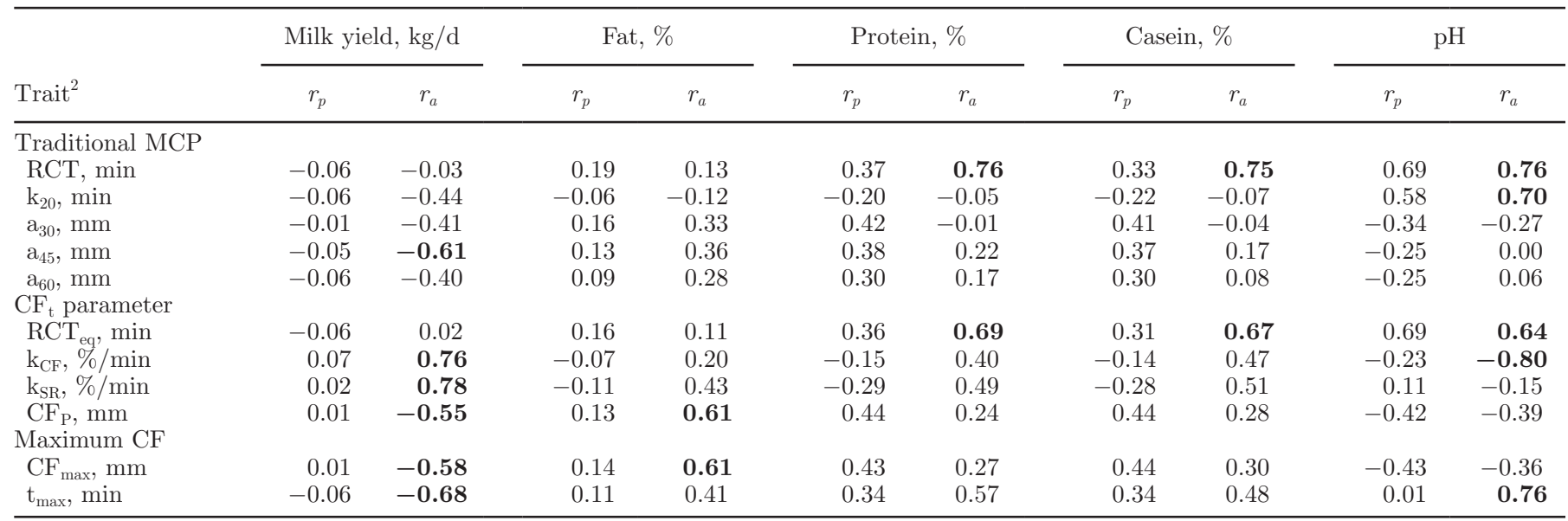

${ }^{1}$ Mean of the marginal posterior density of the correlation; bold indicates additive genetic correlations with $\geq 90 \%$ of posterior probability accumulated above 0 (positive estimates) or below 0 (negative estimates).

${ }^{2} \mathrm{RCT}=$ rennet coagulation time of samples coagulating within $60 \mathrm{~min}$ from enzyme addition; $\mathrm{k}_{20}=$ curd-firming time of samples reaching 20 $\mathrm{mm}$ of firmness within 60 min from enzyme addition; $\mathrm{a}_{30}=$ curd firmness at 30 min after enzyme addition; $\mathrm{a}_{45}=$ curd firmness at 45 min after enzyme addition; $\mathrm{a}_{60}=$ curd firmness at 60 min after enzyme addition; $\mathrm{RCT}_{\mathrm{eq}}=$ rennet coagulation time estimated using the $\mathrm{CF}_{\mathrm{t}}$ equation; $\mathrm{CF}_{\mathrm{P}}$ $=$ asymptotic potential curd firmness; $\mathrm{k}_{\mathrm{CF}}=$ curd firming instant rate constant; $\mathrm{k}_{\mathrm{SR}}=$ syneresis instant rate constant; $\mathrm{CF}_{\max }=\operatorname{maximum}$ curd firmness attained within $45 \mathrm{~min} ; \mathrm{t}_{\max }=$ time at attainment of $\mathrm{CF}_{\max }$. 


\section{REFERENCES}

Astruc, J. M., F. Barillet, A. Carta, M. Fioretti, E. Gootwine, D Kompan, F. J. Romberg, and E. Ugarte. 2008. Report of the working group on milk recording of sheep. Pages 275-282 in Proc. 36th Biennial Session of the International Committee for Animal Recording (ICAR), Niagara Falls, NY. ICAR technical series no. 13 Identification, breeding, production, health and recording on farm animals. J. D. Slatter, ed. ICAR, Rome, Italy.

Baro, J. A., J. A. Carriedo, and F. San Primitivo. 1994. Genetic parameters of test day measures for somatic cell count, milk yield, and protein percentage of milking ewes. J. Dairy Sci. 77:2658-2662.

Bencini, R. 2002. Factors affecting the clotting properties of sheep milk. J. Sci. Food Agric. 82:705-719.

Bittante, G. 2011. Modeling rennet coagulation time and curd firmness of milk. J. Dairy Sci. 94:5821-5832.

Bittante, G., C. Cipolat-Gotet, and A. Cecchinato. 2013a. Genetic parameters of different measures of cheese yield and milk nutrient recovery from an individual model cheese-manufacturing process. J. Dairy Sci. 96:7966-7979.

Bittante, G., C. Cipolat-Gotet, F. Malchiodi, E. Sturaro, F. Tagliapietra, S. Schiavon, and A. Cecchinato. 2015. Effect of dairy farming system, herd, season, parity and days in milk on modeling of coagulation, curd firming, and syneresis of bovine milk. J. Dairy Sci. 98:2759-2774

Bittante, G., B. Contiero, and A. Cecchinato. 2013b. Prolonged observation and modelling of milk coagulation, curd firming, and syneresis. Int. Dairy J. 29:115-123.

Bittante, G., E. Pellattiero, F. Malchiodi, C. Cipolat-Gotet, M. Pazzola, G. M. Vacca, S. Schiavon, and A. Cecchinato. 2014. Quality traits and modelling of coagulation, curd firming and syneresis of sheep milk of Alpine breeds fed diets supplemented with rumenprotected conjugated fatty acid. J. Dairy Sci. 97:4018-4028.

Bittante, G., M. Penasa, and A. Cecchinato. 2012. Invited review: Genetics and modeling of milk coagulation properties. J. Dairy Sci. 95:6843-6870.

Carta, A., S. Casu, and S. Salaris. 2009. Invited review: Current state of genetic improvement in dairy sheep. J. Dairy Sci. 92:5814-5833.

Carta, A., S. R. Sanna, and S. Casu. 1998: The use of equivalent mature ewe for the genetic evaluation of Sarda dairy sheep. Proceedings of the 6th World Congress on Genetics Applied to Livestock Production. Armidale, NSW, Australia. 24:173-176.

Cecchinato, A., S. Chessa, C. Ribeca, C. Cipolat-Gotet, T. Bobbo, J. Casellas, and G. Bittante. 2015. Genetic variation and effects of candidate-gene polymorphisms on coagulation properties, curd firmness modeling and acidity in milk from Brown Swiss cows. Animal 9:1104-1112.

Cecchinato, A., C. Cipolat-Gotet, J. Casellas, M. Penasa, A. Rossoni, and G. Bittante. 2013. Genetic analysis of rennet coagulation time, curd-firming rate, and curd firmness assessed over an extended testing period using mechanical and near-infrared instruments. J. Dairy Sci. 96:50-62.

Cecchinato, A., C. Ribeca, A. Maurmayr, M. Penasa, M. De Marchi, N. P. P. Macciotta, M. Mele, P. Secchiari, G. Pagnacco, and G. Bittante. 2012. Short communication: Effects of $\beta$-lactoglobulin, stearoyl-coenzyme A desaturase 1, and sterol regulatory element binding protein gene allelic variants on milk production, composition, acidity, and coagulation properties of Brown Swiss cows. J. Dairy Sci. 95:450-454.

Dadousis, C., S. Biffani, C. Cipolat-Gotet, E. L. Nicolazzi, A. Rossoni, E. Santus, G. Bittante, and A. Cecchinato. 2016. Genomewide association of coagulation properties, curd firmness modeling, protein percentage, and acidity in milk from Brown Swiss cows. J. Dairy Sci. 99:3654-3666. http://dx.doi.org/10.3168/jds.201510078. de la Fuente, L. F., C. Gonzalo, J. P. Sánchez, R. Rodriguez, J. A. Carriedo, and F. San Primitivo. 2011. Genetic parameters of the linear body conformation traits and genetic correlations with udder traits, milk yield and composition, and somatic cell count in dairy ewes. Can. J. Anim. Sci. 91:585-591.

el-Saied, U. M., J. A. Carriedo, L. F. de la Fuente, and F. San Primitivo. 1999. Genetic parameters of lactation cell counts and milk and protein yields in dairy ewes. J. Dairy Sci. 82:639-644.

FAOSTAT. 2014. Statistical Database of the Food and Agriculture Organization of the United Nations. Accessed Jun. 13, 2014. http:// www.faostat.fao.org.

Gregersen, V. R., F. Gustavsson, M. Glantz, O. F. Christensen, H. Stålhammar, A. Andrén, H. Lindmark-Månsson, N. A. Poulsen, L. B. Larsen, and M. Paulsson. 2015. Bovine chromosomal regions affecting rheological traits in rennet-induced skim milk gels. J. Dairy Sci. 98:1261-1272.

Gutiérrez, J. P., E. Legaz, and F. Goyache. 2007. Genetic parameters affecting 180-days standardised milk yield, test-day milk yield and lactation length in Spanish Assaf (Assaf.E) dairy sheep. Small Rumin. Res. 70:233-238.

Macciotta, N. P. P., M. Mele, A. Cappio-Borlino, and P. Secchiari. 2005. Issues and perspectives in dairy sheep breeding. Ital. J. Anim. Sci. 4:5-23.

McMahon, D. J., and R. J. Brown. 1982. Evaluation of Formagraph for comparing rennet solutions. J. Dairy Sci. 65:1639-1642.

Othmane, M. H., J. A. Carriedo, F. San Primitivo, and L. F. de la Fuente Crespo. 2002a. Genetic parameters for lactation traits of milking ewes: Protein content and composition, fat, somatic cells and individual laboratory cheese yield. Genet. Sel. Evol. 34:581596.

Othmane, M. H., L. F. de la Fuente Crespo, J. A. Carriedo, and F. San Primitivo. 2002b. Heritability and genetic correlations of test day milk yield and composition, individual laboratory cheese yield and somatic cell count for dairy ewes. J. Dairy Sci. 85:2692-2698.

Park, Y. W., M. Juarez, M. Ramos, and G. F. W. Haenlein. 2007 Physico-chemical characteristics of goat and sheep milk. Small Rumin. Res. 68:88-113.

Pazzola, M., M. L. Dettori, C. Cipolat-Gotet, A. Cecchinato, G. Bittante, and G. M. Vacca. 2014. Phenotypic factors affecting coagulation properties of milk from Sarda ewes. J. Dairy Sci. 97:72477257

Pollott, G. E., and E. Gootwine. 2001. A genetic analysis of complete lactation milk production in improved Awassi sheep. Livest. Prod. Sci. 71:37-47.

Riggio, V., B. Portolano, H. Bovenhuis, and S. C. Bishop. 2010. Genetic parameters for somatic cell score according to udder infection status in Valle del Belice dairy sheep and impact of imperfect diagnosis of infection. Genet. Sel. Evol. 42:30.

Sanna, S. R., A. Carta, and S. Casu. 2002. Genotype by environment interaction for milk yield in Sarda dairy sheep. J. Anim. Breed. Genet. 119:190-199.

Sorensen, D., and D. Gianola. 2002. Likelihood, Bayesian, and MCMC Methods in Quantitative Genetics. Springer-Verlag, New York, NY.

Tyrisevä, A.-M, K. Elo, A. Kuusipuro, V. Vilva, I. Jänönen, H. Karjalainen, T. Ikonen, and M. Ojala. 2008. Chromosomal regions underlying noncoagulation of milk in Finnish Ayrshire cows. Genetics 180:1211-1220.

Tyrisevä, A.-M., T. Ikonen, and M. Ojala. 2003. Repeatability estimates for milk coagulation traits and non-coagulation of milk in Finnish Ayrshire cows. J. Dairy Res. 70:91-98.

Vacca, G. M., M. Pazzola, M. L. Dettori, E. Pira, F. Malchiodi, C. Cipolat-Gotet, A. Cecchinato, and G. Bittante. 2015. Modeling of coagulation, curd firming, and syneresis of milk from Sarda ewes. J. Dairy Sci. 98:2245-2259. 